\title{
Analisis Kondisi Keuangan Perusahaan dengan menggunakan Model Altman (Z-Score) dan Zavgren (Logit) (Studi Kasus pada Perusahaan Farmasi yang Terdaftar di Bursa Efek Indonesia Periode 2011-2015)
}

\author{
Indra Krishernawan \\ Program Studi Manajemen STIE Al-Anwar Mojokerto \\ e-mail: indra krishernawan@gmail.com \\ Cahyani Indrawati \\ Program Studi Manajemen STIE Al-Anwar Mojokerto \\ e-mail: cahyani.indrawati2000@gmail.com
}

\begin{abstract}
Abstrak
Penelitian ini bertujuan untuk menentukan kondisi keuangan dari perusahaan farmasi yang terdaftar di Bursa Efek Indonesia (BEI) selama periode 2011-2015 menggunakan Model Altman (Z-Score) dan Model Zavgren (Logit), serta untuk menentukan apakah terdapat perbedaan yang signifikan antara kedua model penilaian tersebut. Sembilan perusahaan farmasi yang terdaftar di BEI terpilih sebagai sampel penelitian menggunakan saturated sampling method. Hasil penelitian menunjukkan bahwa berdasarkan Model Altman pada tahun 2011 terdapat 6 perusahaan sehat, 1 kritis dan 2 berpotensi bangkrut; tahun 2012 terdapat 5 perusahaan sehat, 3 kritis dan 1 berpotensi bangkrut; tahun 2013 terdapat 6 perusahaan sehat, 2 kritis dan 1 berpotensi bangkrut; tahun 2014 terdapat 5 perusahaan sehat, 2 kritis dan 2 berpotensi bangkrut; serta, tahun 2015 terdapat 6 perusahaan sehat dan 1 kritis. Apabila berdasarkan Model Zavgren diidentifikasi pada tahun 2011 terdapat 7 perusahaan sehat dan 2 berpotensi bangkrut; tahun 2012 terdapat 6 perusahaan sehat dan 3 berpotensi bangkrut; tahun 2013 terdapat 7 perusahaan sehat dan 2 berpotensi bangkrut; tahun 2014 terdapat 6 perusahaan sehat dan 3 berpotensi bangkrut; serta, tahun 2015 terdapat 7 perusahaan sehat dan 2 berpotensi bangkrut. Terakhir, berdasarkan hasil analisis Chi-Square, ada perbedaan signifikan antara hasil penilaian menggunakan Model Altman dan Model Zavgren.
\end{abstract}

Kata kunci: Kondisi keuangan, Model Altman, Model Zavgren, perusahaan farmasi.

\section{PENDAHULUAN}

Semakin global dunia perekonomian menyebabkan persaingan antar perusahaan menjadi semakin ketat, tidak hanya dalam suatu Negara tapi juga dengan perusahaan dinegara lain. Persaingan yang semakin ketat ini menuntut perusahaan untuk selalu memperkuat diri menghadapi perusahaan lain. Ketidakmampuan mengantisipasi trend perkembangan global dengan memperkuat fundamental manjemenakan mengakibatkan pengecilan volume usaha yang pada akhirnya mengakibatkan kebangkrutan perusahaan.
Menurut Darsono (2005), pengertian laporan keuangan adalah alat manajemen untuk mempertanggungjawabkan aktivitas pengelolaan perusahaan yang dipercayakan kepadanya. Laporan keuangan berfungsi untuk menilai kinerja manajemen dalam mengelola sumber daya yang dimiliki untuk memaksimalkan kekayaan dari pemegang saham sebagai pemilik.

Perusahaan yang berkeinginan tetap berkembang di tuntutan dan manajemen yang berkualitas untuk mengelola perusahaan dan melihat peluang yang ada sehingga dirinya 
bisa mempertahankan kelangsungan hidup perusahaan dari kebangkrutan. Dengan penggunaan laporan keuangan dalam menganalisis kondisi keuangan perusahaan secara menyeluruh dapat menjadi media informasi yang digunakan para investor untuk menanamkan dananya pada perusahaan. Investor dan kreditor sebagai pihak yang berada diluar perusahaan dituntut mengetahui perkembangan yang ada dalam perusahaan untuk mengamankan investasi yang telah dilakukan. Ketidakmampuan untuk membaca sinyal-sinyal dalam kesulitan usaha akan mengakibatkan kerugian di dalam investasi yang telah dilakukan. Untuk mengantisipasi hal tersebut investor harus bisa mendeteksi kesulitan yang dialami oleh perusahaan.

Risiko kebangkrutan bagi perusahaan dapat dilihat dan diukur melalui laporan keuangan, dengan cara melakukan analisis terhadap laporan keuangan yang dikeluarkan oleh perusahaan yang bersangkutan. Analisis rasio merupakan analisis yang sering digunakan dalam menilai kinerja keuangan perusahaan, salah satu sumber utamanya adalah dengan melihat dari laporan keuangan perusahaan.

Menurut Altman (1968), dengan menggunakan lima rasio keuangan yang dianggap paling berkontribusi dalam model prediksi kebangkrutan dengan menggunakan satu model persamaan. Model Altman (ZScore) mengkombinasikan beberapa rasio keuangan yang terdapat pada laporan keuangan menjadi model prediksi dengan teknik statistik. Model ini juga dikenal dengan Multiple Discriminant Analysis. Variabel yang digunakan yaitu rasio modal kerja per/total aktiva, rasio laba ditahan/total aktiva, rasio EBIT/total aktiva, rasio nilai buku ekuitas/nilai buku hutang dan rasio penjualan/aktiva.

Stickney (1996 dalam Dewi, 2015) mengemukakan tentang Christine Zavgren yang pada tahun 1985 mengembangkan model prediksi kebangkrutan dengan menggunakan metode analisis logit, yang menghasilkan probabilitas atau kemungkinan kebangkrutan. Model ini menggunakan rasio likuiditas, rasio aktivitas, rasio solvabilitas dan rasio profitabilitas. Selain kelompok rasio tersebut, model Zavgren (Logit) juga memperhitung kan rasio piutang terhadap persediaan.

Di Indonesia, ada sektor perusahaan yang perlu diprediksi kebangkrutannya. Hal ini dikarenakan dalam beberapa tahun ini terdapat banyak kendala perusahaan yang berpotensi mengalami kebangkrutan. Pada tahun 2015, perlambatan ekonomi yang terjadi menekan kinerja sejumlah industri, tak terkecuali industri farmasi. Pelemahan daya beli dan fluktuaktif nilai tukar rupiah menjadikan profitabilitas perusahaan farmasi menurun. Menurut Ketua Umum dari International Pharmaceutical Manufactures Group (IPMG), Lutfhi Mardiansyah, industry farmasi di Indonesia melakukan pemutusan hubungan kerja dalam beberapa tahun terakhir. Beberapa perusahaan yang tidak berhasil meningkatkan penjualannya, bahkan ada yang mengalami kerugian. Memasuki tahun 2016 diprediksi industri farmasi masih mendapat tekanan berat, ditengah kondisi ketergantungan impor bahan baku yang masih diatas 90\%. Tantangan bagi industri bahan baku farmasi di Indonesia adalah pasar dalam negeri yang relatif kecil, profit margin juga kecil, sementara investasi awal sangat besar. Kondisi tersebut membuat industri bahan baku farmasi Indonesia tidak bisa bersaing dalam situasi harga global.

Pada tahun 2012 mencapai 13\%, tahun 2013 tidak mengalami peningkatan dan penurunan, pesentase pertumbuhan tetap sama pada tahun sebelumnya, yaitu $13 \%$. Tahun 2014 pertumbuhan perusahaan mengalami penurunan $5,8 \%$ menjadi $7,2 \%$; dan pada tahun 2015 tingkat pertumbuhan perusahaan meningkat tetapi hanya sebesar $0,9 \%$ yaitu menjadi $7,9 \%$. Pertumbuhan perusahaan farmasi dari tahun 2012 hingga 2015 sangat fluktuaktif. Dengan keadaan pertumbuhan yang berfluktuasi maka pihak investor perlu mengetahui cara mendeteksi resiko kerugian yang dihadapi dengan tingkat keuntungan yang akan diperoleh.

Berdasarkan fakta dan permasalahan yang ada, maka penelitian ini dilakukan untuk memprediksi kebangkrutan pada perusahaan farmasi yang terdaftar di Bursa Efek 
Indonesia periode 2011-2015 menggunakan model Altman (Z-Score) dan model Zavgren (Logit) yang diharapkan dapat memberikan hasil yang baik, sehingga dapat menjadi rujukan dalam penelitian mengenai prediksi kebangkrutan pada perusahaan di Indonesia.

Berdasarkan latar belakang masalah tersebut maka rumusan masalah dalam penelitian ini adalah bagaimana kondisi keuangan perusahaan farmasi yang terdaftar di Bursa Efek Indonesia periode 2011- 2015 menurut model Altman (Z-Score) dan model Zavgren (Logit), serta apakah terdapat perbedaan hasil penilaian kondisi keuangan perusahaan farmasi yang terdaftar di Bursa Efek Indonesia (BEI) periode 2011-2015 menurut model Altman (Z-Score) dan model Zavgren (Logit). Batasan masalah dimana analisis kondisi keuangan dan prediksi kebangkrutan perusahaan tersebut difokuskan hanya pada kodisi keuangan dan prediksi kebangkrutan dengan menggunakan metode Altman (Z-Score) dan metode Zavgren (Logit) untuk periode 2011-2015. Selain itu, obyek penelitian ini juga hanya pada Perusahaan Farmasi yang Terdaftar di BEI.

\section{Laporan Keuangan}

Laporan keuangan merupakan suatu informasi yang menggambarkan kondisi keuangan perusahaan, dan lebih jauh informasi tersebut dapat dijadikan sebagai gambaran kinerja keuangan perusahaan tersebut (Fahmi, 2012).

Laporan keuangan merupakan ringkasan dari suatu proses pencatatan, yang merupakan suatu ringkasan dari transaksi-transaksi keuangan yang terjadi selama tahun buku yang bersangkutan (Baridwan, 2010).

Dari definisi-definisi tersebut dapat disimpulkan bahwa laporan keuangan merupakan ringkasan proses pencatatan transaksi-transaksi keuangan yang terjadi selama tahun buku yang laporan keuangan meliputi neraca (menggambarkan informasi posisi keuangan), laporan laba rugi (menggambarkan informasi kinerja), laporan perubahan posisi keuangan yang dapat disajikan dalam berbagai cara, catatan dan laporan lain, serta materi penjelasan, yang merupakan bagian integral dari laporan keuangan.

\section{Analisis Laporan Keuangan}

Menurut Harahap (2011), yang dimaksud analisis laporan keuangan berarti menguraikan pos-pos laporan keuangan menjadi unit informasi yang lebih kecil dan melihat hubungannya bersifat signifikan atau mempunyai makna antara satu sama lain, baik antara data kuantitatif maupun data non kuantitatif dengan tujuan untuk mengetahui kondisi keuangan yang lebih dalam yang sangat penting dalam proses menghasilkan keputusan yang tepat.

Sedangkan menurut Darsono (2005), analisis laporan keuangan menggunakan teknik analisis rasio dan analisis presentase yang memungkinkan untuk mengidentifikasi, mengkaji serta merangkum pola-pola hubungan yang signifikan dari data keuangan perusahaan.

Dari definisi tersebut yang dimaksud analisis laporan keuangan mencakup pengaplikasian berbagai alat dan teknik analisis pada laporan, dan data keuangan dalam rangka untuk memperoleh ukuranukuran dan hubungan-hubungan yang berarti dan berguna dalam pengambilan keputusan.

\section{Kinerja Keuangan Perusahaan}

Menurut Fahmi (2012), kinerja keuangan merupakan gambaran dari pencapaian keberhasilan perusahaan dapat diartikan sebagai hasil yang telah dicapai atas berbagai aktivitas yang telah dilakukan. Bisa dijelaskan bahwa kinerja keuangan adalah suatu analisis yang dilakukan untuk melihat sejauh mana suatu perusahaan telah melaksanakan dengan menggunakan aturanaturan pelaksanaan keuangan secara baik dan benar.

Sementara Mulyadi (2007) menyebut pengertian kinerja keuangan ialah penentuan secara periodik efektifitas operasional suatu organisasi dan karyawannya berdasarkan sasaran, standar, dan kriteria yang ditetapkan sebelumnya. Menurut Jumingan (2006), kinerja keuangan adalah gambaran kondisi keuangan perusahaan pada suatu periode 
tertentu baik terkait aspek penghimpunan dana maupun penyaluran dana, yang biasanya diukur dengan indikator kecukupan modal, likuiditas, dan profitabilitas.

Dari sejumlah pengertian kinerja keuangan itu, dapat diambil kesimpulan sederhana bahwa kinerja keuangan merupakan pencapaian prestasi perusahaan pada suatu periode yang menggambarkan kondisi kesehatan keuangan perusahaan dengan indikator kecukupan modal, likuiditas dan profitabilitas.

\section{Analisis Rasio Keuangan}

Menurut Darsono (2005), yang dimaksud analisis rasio keuangan adalah analisis perbandingan dengan industri sejenis atau analisis perbandingan rasio periode saat ini dengan rasio periode sebelumnya.

Munawir (2007) menyatakan analisa rasio seperti halnya alat analisa yang lain "future oriented". Oleh karena itu, penganalisa harus mampu menyesuaikan faktor-faktor yang ada pada periode atau waktu ini dengan faktor-faktor di masa akan datang yang mungkin akan mempengaruhi posisi keuangan ataupun hasil operasi perusahaan yang bersangkutan.

Menurut Fahmi (2012), pengertian analisis rasio keuangan dimulai dengan laporan keuangan dasar, yaitu dari neraca (balance sheet), perhitungan rugi laba (income statement), dan laporan arus kas (cash flow statement).

Dari definisi-definisi tersebut dapat disimpulkan bahwa analisis rasio keuangan adalah suatu alat analisis perbandingan rasio keuangan yang bertujuan menganalisis dan menginterprestasikan posisi keuangan suatu perusahaan, dengan menggunakan laporan yang diperbandingkan, termasuk tentang perubahan-perubahan yang terjadi dalam jumlah rupiah, persentase serta trendnya.

\section{Kebangkrutan}

Menurut Darsono (2005), kesulitan keuangan diartikan sebagai ketidakmampuan perusahaan untuk membayar kewajiban keuangannya pada saat jatuh tempo yang menyebabkan kebangkrutan perusahaan.
Foster (1986 dalam Darsono, 2005) mengemukakan bahwa kesulitan keuangan menunjukkan adanya masalah likuiditas yang parah yang tidak dapat dipecahkan tanpa melalui penjadwalan kembali secara besarbesaran terhadap operasi dan struktur perusahaan.

Jadi, yang dimaksud kebangkrutan adalah suatu keadaan atau situasi dimana perusahaan mengalami kekurangan ataupun ketidakcukupan dana untuk memenuhi kewajiban-kewajibannya kepada kreditur serta tak bisa menjalankan atau melanjutkan usahanya.

\section{Model Altman (Z-Score)}

Analisis diskriminan merupakan suatu teknik statistika yang dapat digunakan untuk pengklasifikasian apakah suatu perusahaan bangkrut atau tidak bangkrut. Seorang profesor bisnis dari NewYork University, Amerika Serikat, Edward Altman, pada tahun 1968 telah mengembangkan sistem scoring secara matematis yang memprediksi kemungkinan kebangkrutan perusahaan.

Analisis kebangkrutan dilakukan untuk mendapatkan peringatan awal kebangkrutan. Makin awal peringatan itu, makin baik bagi pihak manajemen dapat dengan segera melakukan perbaikan-perbaikan. Model ZScore merupakan suatu model yang dapat digunakan untuk memprediksi kesulitan keuangan. Tujuan dari perhitungan Z-Score adalah mengingatkan akan masalah keuangan yang mungkin membutuhkan perhatian serius. Z-Score adalah skor yang ditentukan dari hitungan standar kali nisbah-nisbah keuangan yang menunjukkan peluang kebangkrutan perusahaan.

Altman mengembangkan suatu model prediksi kebangkrutan dengan menggunakan lima variabel, dengan persamaan sebagai berikut (Supardi \& Mastuti, 2003):

$$
\begin{aligned}
\mathrm{Z}= & 0,717 \mathrm{X} 1+0,847 \mathrm{X} 2+3,107 \mathrm{X} 3+0,420 \mathrm{X} 4 \\
& +0,998 \mathrm{X} 5
\end{aligned}
$$

dimana X1 adalah total aktiva, X2 adalah perbandingan antara laba ditahan dan total aktiva, X3 adalah perbandingan antara EBIT dan total aktiva, X4 adalah perbandingan antara nilai buku ekuitas dan nilai buku 
hutang, dan X5 adalah perbandingan antara penjualan dan total aktiva.

Batas sehat tidaknya kondisi suatu perusahaan yang dianalisis didasarkan pada cut-off point dengan ketentuan sebagai berikut (Supardi \& Mastuti, 2003):

1. Perusahaan dinilai berada dalam kondisi tidak sehat atau mempunyai probabilitas tingkat kebangkrutan yang tinggi bila nilai Z kurang dari 1,20 (Z-Score $<1,20)$.

2. Perusahaan dinilai dalam kondisi sehat atau mempunyai probabilitas tingkat kebangkrutan yang rendah bila nilai $\mathrm{Z}$ lebih besar dari 2,90 (Z-Score > 2,90).

3. Apabila nilai $Z$ yang dihasilkan antara 1,20 sampai dengan 2,90 $(1,20<Z<2,90)$ dikatakan bahwa perusahaan terletak dalam "gray area" yang berarti perusahaan mempunyai kemungkinan untuk dikategorikan dalam perusahaan yang sehat maupun tidak sehat.

\section{Model Zavgren (Logit)}

Tahap pengembangan metodologi penelitian relatif baru untuk menghitung risiko tekanan keuangan (Financial Distress Risk) telah dilakukan sepanjang tahun 1980an dan permulaan tahun 1990-an dengan menggunakan analisis logit (Logit Analysis) disamping menggunakan analisis Multiple Discriminant Analysis.

Analisis Logit awal ditemukan oleh Christine V. Zavgren dengan mengadakan penelitian pada 45 perusahaan dalam keadaan bangkrut dan 45 perusahaan tidak bangkrut, serta memperhitungkan ukuran asset dan industri serupa. Aplikasi dari model Zavgren (Logit) membutuhkan empat langkah (Zavgren, 1983), yaitu: (1)menghitung serangkaian tujuh rasio keuangan; (2)setiap rasio dikalikan dengan koefiesien khusus; (3)nilai atau hasil yang diperoleh dijumlahkan secara bersama (Y); dan, (4)probabilitas kebangkrutan perusahaan dikalkulasi dengan fungsi probabilitas logit.

Christine V. Zavgren menetapkan formula untuk menghitung probabilitas kebangkrutan perusahaan (Stickney, 1996 dalam Rakhmawati, 2010):

$$
P_{i}=\frac{1}{1+e^{y}}
$$

$P_{i}$ adalah probabilitas kebangkrutan perusahaan. Eksponen $y$ adalah fungsi multivarian yang terdiri dari satu tetapan konstanta dan berbagai koefisien atas variabel bebas. Variabel bebas mencakup tujuh rasio laporan keuangan yang meliputi rasio-rasio INV, REC, CASH, QUICK, ROI, DEBT, dan TURNOVER.

Nilai eksponen $y$ dapat dihitung dengan menggunakan formula (Stickney, 1996 dalam Rakhmawati, 2010):

$$
\begin{aligned}
\mathrm{Y}= & 0,23883-0,108(\mathrm{INV})-1,583(\mathrm{REC})-10,78 \\
& (\mathrm{CASH})+3,074(\mathrm{QUICK})+0,486(\mathrm{ROI})- \\
& 4,35(\mathrm{DEBT})+0,11(\mathrm{TURN})
\end{aligned}
$$

dimana INV adalah rata-rata persediaan dibandingkan penjualan; REC adalah rata-rata piutang dibandingkan rata-rata persediaan; CASH adalah penjumlahan kas dan surat berharga dibandingkan total aktiva; QUICK adalah quick asset dibandingkan hutang lancar; ROI adalah laba operasi bersih dibandingkan selisih antara total aktiva dan hutang lancar; DEBT adalah hutang jangka panjang dibandingkan selisih antara total aktiva dan hutang lancar; dan, TURN adalah penjualan dibandingkan penjumlahan antara modal kerja dan aktiva tetap.

Variabel bebas berkoefisien negatif bisa meningkatkan probabilitas kebangkrutan, karena koefisien negatif akan menurunkan $e_{y}$ hingga mendekati angka nol, $P_{i}$ (probabilitas kebangkrutan perusahaan) mendekati $1 / 1$ atau $100 \%$. Sedangkan variabel bebas berkoefisien positif dapat menurunkan probabilitas kebangkrutan perusahaan, karena koefisien positif bisa meningkatkan $e_{y}$ hingga mendekati bilangan positif tak terhingga $(\sim)$ yang mengakibatkan $P_{i}$ (probabilitas kebangkrutan perusahaan) mendekati angka nol.

\section{Kerangka Pikir dan Hipotesis}

Dari laporan keuangan di suatu perusahaan dapat dicari rasio-rasio keuangan yang ada dalam model Altman (Z-Score) dan model Zavgren (Logit). Dari hasil kedua model itu bisa digunakan untuk menganalisis kondisi keuangan perusahaan dan apakah 
terdapat perbedaan penilaian kondisi keuangan perusahaan.

\section{METODE PENELITIAN}

Jenis data yang dipergunakan dalam penelitian ini adalah data kuantitatif. Sumber data yang digunakan dalam penelitian ini adalah data sekunder yang diperoleh dari laporan publikasi BEI dalam www.idx.co.id yang berupa laporan keuangan tahunan.

Model yang digunakan dalam penelitian ini terdiri model Altman (Z-Score) dan model Zavgren (Logit). Pada model Altman (ZScore) terdiri dari lima indikator, yaitu rasio modal kerja/total aktiva sebagai X1; rasio laba ditahan/total aktiva sebagai X2; rasio EBIT/ total aktiva sebagai $\mathrm{X} 3$; rasio nilai buku ekuitas/nilai buku hutang sebagai $\mathrm{X} 4$; dan rasio penjualan/total aktiva sebagai X5. Sedangkan pada model Zavgren (Logit) terdiri dari tujuh indikator, yaitu INV, REC, CASH, QUICK, ROI, DEBT, dan TURNOVER.

Analisis data yang digunakan adalah analisis model Altman (Z-Score) dan analisis model Zavgren (Logit), serta perbandingan kondisi keuangan dan dilanjutkan pengujian hipotesis dengan chi-square menggunakan bantuan programSPSS versi 16 for Windows.

Metode Analisis Model Altman (ZScore) menggunakan tahapan sebagai berikut (Supardi \& Mastuti, 2003), yaitu:

1. Menghitung rasio keuangan;

2. Melakukan perhitungan dengan analisis model Altman (Z-Score) dengan rumus:

$$
\begin{aligned}
Z= & 0,717 X_{1}+0,847 X_{2}+3,107 X_{3}+ \\
& 0,420 X_{4}+0,998 X_{5}
\end{aligned}
$$

3. Melakukan interpretasi hasil perhitungan atau klasifikasi sesuai dengan titik cut-off yang telah ditentukan:

- $\mathrm{Z} \leq 1,20$ berarti perusahaan dalam kondisi potensial bangkrut.

- 1,20<Z<2,90 berarti perusahaan dalam kondisi kritis/rawan.

- $\mathrm{Z} \geq 2,90$ berarti perusahaan dalam kondisi sehat.

Metode Analisis Model Zavgren (Logit) menggunakan tahapan sebagai berikut:

1. Menghitung rasio keuangan;
2. Melakukan perhitungan dengan analisis model Zavgren (Logit) dengan rumus:

$$
P_{i}=\frac{1}{1+e^{y}}
$$

dimana $P_{i}$ adalah probabilitas kebangkrutan perusahaan.

$$
\begin{aligned}
\mathrm{Y}= & 0,23883-0,108(\mathrm{INV})-1,583 \text { (REC)- } \\
& 10,78(\mathrm{CASH})+0,074(\mathrm{QUICK})+0,486 \\
& (\mathrm{ROI})-4,35(\mathrm{DEBT})+0,11(\mathrm{TURN})
\end{aligned}
$$

Setelah didapatkan hasil nilai $P_{i}$, maka data yang ada diuji lagi dengan alat statistic karena model logit Zavgren tidak memiliki titik cut-off untuk mendapatkan kepastian yang tinggi.

Selanjutnya, dilakukan perbandingan keuangan dengan metode analisis komparatif. Analisis komparatif adalah mebandingkan hasil perhitungan yang diperoleh antara model Altman (Z-Score) dan model Zavgren (Logit).

\section{Pengujian Hipotesis}

Untuk mengetahui apakah terdapat perbedaan antara penilaian kondisi keuangan perusahaan dengan menggunakan model Altman (Z-Score) dan model Zavgren (Logit) maka dilakukan analisis Chi-Square. Dengan kata lain pengujian ini dilakukan untuk menguji hipotesis tentang ada tidaknya perbedaan penilaian kondisi keuangan dengan menggunakan model Altman dengan model Zavgren.

\section{HASIL ANALISIS}

Pada Tabel 1 dapat dilihat bahwa menurut model Altman (Z-Score) kondisi keuangan perusahaan farmasi yang terdaftar di Bursa Efek Indonesia (BEI) selama periode 2011-2015 yang termasuk kategori sehat sebanyak 28 perusahaan, kritis sebanyak 25 perusahaan, dan potensial bangkrut sebanyak 6 perusahaan.

Pada Tabel 2 dapat dilihat bahwa menurut model Zavgren (Logit), kondisi keuangan perusahaan farmasi yang terdaftar di Bursa Efek Indonesia (BEI) selama periode 2011-2015 yang termasuk kategori sehat sebanyak 33 perusahaan, tak ada perusahaan 
yang terkategori kritis, dan potensial bangkrut sebanyak 12 perusahaan.

Berikutnya, pada Tabel 3 ditampilkan hasil perbandingan kondisi keuangan atas perusahaan farmasi yang diteliti antara menggunakan model Altman (Z-Score) dan model Zavgren (Logit) selama periode 20112015. Perusahaan-perusahaan farmasi yang diteliti adalah PT. Darya Varia Laboratoria Tbk. (DVLA), PT. Indofarma (Persero) Tbk. (INAF), PT. Kimia (Persero) Tbk. (KAEF), PT. Kalbe Farma Tbk. (KLBF), PT. Merck Tbk. (MERK), PT. Pyridam Farma Tbk. (PYFA), PT. Schering Plough Indonesia Tbk. (SCPI), PT. Taisho Pharmaceutical Indonesia Tbk. (SQBB), dan PT. Tempo Scan Pacific Tbk. (TSPC).

Hasil analisis keuangan menggunakan kedua model, terdapat perbedaan kondisi keuangan. Analisis keuangan menggunakan model Altman (Z-Score) menyatakan kondisi sehat disebabkan oleh modal kerja, nilai buku ekuitas dan penjualan yang tinggi, sedangkan pada kondisi bangkrut disebabkan oleh nilai buku hutang yang tinggi. Pada analisis keuangan menggunakan model Zavgren (Logit), kondisi sehat disebabkan rasio-rasio CASH, QUICK, ROI dan TURN yang tinggi, sedangkan kondisi bangkrut disebabkan oleh rasio-rasio INV, REC, dan DEBT yang tinggi.

\section{Pengujian Hipotesis}

Hasil analisis Chi-Square memakai SPSS 16 diperoleh nilai $\mathrm{X}_{2}$-hitung sebesar 13,410 dan $X_{2}$-tabel sebesar 5,990. Dengan demikian, Ho ditolak dan ditarik kesimpulan bahwa terdapat perbedaan proporsi antara hasil penilaian kondisi keuangan perusahaan dengan menggunakan model Altman (ZScore) dan model Zavgren (Logit).

Tabel 1. Hasil Analisis dengan Model Altman (Z-score)

Periode 2011-2015

\begin{tabular}{|c|c|c|c|c|c|c|}
\hline \multirow{2}{*}{ Kategori } & \multicolumn{5}{|c|}{ Jumlah (perusahaan) } & \multirow{2}{*}{ Total } \\
\hline & 2011 & 2012 & 2013 & 2014 & 2015 & \\
\hline Sehat & 6 & 5 & 6 & 5 & 6 & 28 \\
\hline Kritis & 1 & 3 & 2 & 2 & 3 & 11 \\
\hline Potensial Bangkrut & 2 & 1 & 1 & 2 & 0 & 6 \\
\hline Total & 9 & 9 & 9 & 9 & 9 & 45 \\
\hline
\end{tabular}

Sumber: Data sekunder (diolah), Tahun 2017.

Tabel 2. Hasil Analisis dengan Model Zavgren (Logit)

Periode 2011-2015

\begin{tabular}{|c|c|c|c|c|c|c|}
\hline \multirow{2}{*}{ Kategori } & \multicolumn{5}{|c|}{ Jumlah (perusahaan) } & \multirow{2}{*}{ Tota } \\
\hline & 2011 & 2012 & 2013 & 2014 & 2015 & \\
\hline Sehat & 7 & 6 & 7 & 6 & 7 & 33 \\
\hline Kritis & 0 & 0 & 0 & 0 & 0 & 0 \\
\hline Potensial Bangkrut & 2 & 3 & 2 & 3 & 2 & 12 \\
\hline Total & 9 & 9 & 9 & 9 & 9 & 45 \\
\hline
\end{tabular}

Sumber: Data sekunder (diolah), Tahun 2017. 
Tabel 3. Perbandingan Hasil Analisis antara Model Altman (Z-score) dan Model Zavgren (Logit) untuk Kondisi Keuangan Perusahaan Farmasi Periode 2011-2015

\begin{tabular}{|c|c|c|c|c|c|c|c|}
\hline \multirow{2}{*}{ No. } & \multirow{2}{*}{$\begin{array}{c}\text { Kode } \\
\text { Perusahaan }\end{array}$} & \multirow{2}{*}{ Model } & \multicolumn{5}{|c|}{ Kondisi Keuangan } \\
\hline & & & 2011 & 2012 & 2013 & 2014 & 2015 \\
\hline \multirow{2}{*}{1} & \multirow{2}{*}{ DVLA } & Altman & Sehat & Sehat & Sehat & Sehat & Sehat \\
\hline & & Zavgren & Sehat & Sehat & Sehat & Sehat & Sehat \\
\hline \multirow{2}{*}{2} & \multirow{2}{*}{ INAF } & Altman & $\begin{array}{l}\text { Potensial } \\
\text { Bangkrut }\end{array}$ & Kritis & Kritis & Kritis & Kritis \\
\hline & & Zavgren & $\begin{array}{l}\text { Potensial } \\
\text { Bangkrut }\end{array}$ & $\begin{array}{l}\text { Potensial } \\
\text { Bangkrut }\end{array}$ & $\begin{array}{l}\text { Potensial } \\
\text { Bangkrut }\end{array}$ & $\begin{array}{l}\text { Potensial } \\
\text { Bangkrut }\end{array}$ & $\begin{array}{l}\text { Potensial } \\
\text { Bangkrut }\end{array}$ \\
\hline \multirow[b]{2}{*}{3} & \multirow[b]{2}{*}{ KAEF } & Altman & Sehat & Sehat & Sehat & Sehat & Sehat \\
\hline & & Zavgren & $\begin{array}{l}\text { Potensial } \\
\text { Bangkrut }\end{array}$ & $\begin{array}{l}\text { Potensial } \\
\text { Bangkrut }\end{array}$ & $\begin{array}{l}\text { Potensial } \\
\text { Bangkrut }\end{array}$ & $\begin{array}{l}\text { Potensial } \\
\text { Bangkrut }\end{array}$ & Sehat \\
\hline \multirow{2}{*}{4} & \multirow{2}{*}{ KLBF } & Altman & Sehat & Sehat & Sehat & Sehat & Sehat \\
\hline & & Zavgren & Sehat & Sehat & Sehat & Sehat & Sehat \\
\hline \multirow{2}{*}{5} & \multirow{2}{*}{ MERK } & Altman & Sehat & Kritis & Sehat & Kritis & Sehat \\
\hline & & Zavgren & Sehat & Sehat & Sehat & Sehat & Sehat \\
\hline \multirow{2}{*}{6} & \multirow{2}{*}{ PYFA } & Altman & Kritis & Kritis & Kritis & & Kritis \\
\hline & & Zavgren & Sehat & Sehat & Sehat & Sehat & Sehat \\
\hline \multirow{2}{*}{7} & \multirow{2}{*}{ SCPI } & Altman & $\begin{array}{l}\text { Potensial } \\
\text { Bangkrut }\end{array}$ & $\begin{array}{l}\text { Potensial } \\
\text { Bangkrut }\end{array}$ & $\begin{array}{l}\text { Potensial } \\
\text { Bangkrut }\end{array}$ & $\begin{array}{l}\text { Potensial } \\
\text { Bangkrut }\end{array}$ & Kritis \\
\hline & & Zavgren & Sehat & $\begin{array}{l}\text { Potensial } \\
\text { Bangkrut }\end{array}$ & Sehat & $\begin{array}{l}\text { Potensial } \\
\text { Bangkrut }\end{array}$ & $\begin{array}{l}\text { Potensial } \\
\text { Bangkrut }\end{array}$ \\
\hline \multirow{2}{*}{8} & \multirow{2}{*}{ SQBB } & Altman & Sehat & Sehat & Sehat & Sehat & Sehat \\
\hline & & Zavgren & Sehat & Sehat & Sehat & Sehat & Sehat \\
\hline \multirow{2}{*}{9} & \multirow{2}{*}{ TSPC } & Altman & Sehat & Sehat & Sehat & Sehat & Sehat \\
\hline & & Zavgren & Sehat & Sehat & Sehat & Sehat & Sehat \\
\hline
\end{tabular}

Sumber: Data sekunder (diolah), Tahun 2017.

\section{KESIMPULAN}

Berdasarkan perbandingan hasil antara model Altman (Z-Score) dan Zavgren (Logit), terdapat beberapa perusahaan yang berbeda hasil. Hasil ini dipengaruhi oleh perbedaan karakteristik dari model-model itu sendiri, dimana penggunaan rasio bisa menyebabkan perbedaan pengkategorian kondisi keuangan perusahaan. Kedua model ini sama-sama merupakan cara peringatan masalah keuangan yang mungkin membutuhkan perhatian serius dan memberikan petunjuk-petunjuk berguna untuk menghindari kesulitan keuangan perusahaan di masa depan. Penggunaan metode tergantung dari persepsi perusahaan menafsirkan kondisi keuangannya yang cenderung melihat pada rasio-rasio yang ditentukan.

Kondisi keuangan perusahaan farmasi yang terdaftar diBursa Efek Indonesia (BEI) periode 2011-2015 menggunakan model Altman (Z-Score) ada tiga kategori, yaitu sehat, kritis dan potensial bangkrut. Dengan kategori sehat sebanyak 28 perusahaan, kritis 25 perusahaan, dan potensial bangkrut sebanyak 6 perusahaan.

Berikutnya, kondisi keuangan yang dialami perusahaan farmasi yang terdaftar di Bursa Efek Indonesia (BEI) periode 20112015 menggunakan model Zavgren (Logit) 
ada tiga kategori, yaitu sehat, kritis dan potensial bangkrut. Hasil analisis memperoleh kategori sehat sebanyak 33 perusahaan, tidak ada perusahaan yang dikategorikan kritis, dan potensial bangkrut sebanyak 12 perusahaan.

Berdasarkan hasil analisis Chi-Square menggunakan SPSS ver.16 ditarik kesimpulan terdapat perbedaan proporsi antara hasil penilaian kondisi keuangan perusahaan menggunakan model Altman (Z-Score) dan model Zavgren (Logit).

Dengan adanya analisis model Altman (Z-Score) dan model Zavgren (Logit), perusahaan bisa memprediksi kondisi dirinya sehingga perusahaan itu dapat melakukan tindakan yang benar dan tepat untuk kelangsungan usahanya. Namun demikian, perusahaan yang diprediksi berpotensi mengalami kebangkrutan pada periode tahun yang diteliti bukan berarti perusahaan itu mengalami kebangkrutan. Hal ini hanya sebagai peringatan bagi perusahaan tentang kondisi keuangan perusahaan tersebut sehingga perusahaan yang bersangkutan bisa mengantisipasi kemungkinan-kemungkinan terburuk yang akan terjadi pada perusahaan di masa yang akan datang serta melakukan perbaikan kinerja dan manajemen pada perusahaan.

Berdasarkan beberapa kesimpulan tersebut, bisa direkomendasikan beberapa hal. Pertama, disarakan para peneliti selanjutnya dapat memasukkan seluruh perusahaan farmasi baik yang terdaftar di Bursa Efek Indonesia (BEI) maupun tidak dalam menentukan titik cut-off pada model Zavgren (Logit), sehingga hasil perhitungan rentang intervalakan lebih akurat bila perusahaanperusahaan farmasi yang tidak terdaftar diBEI juga ikut dimasukkan dalam perhitungan.

Kedua, disarankan bagi perusahaan bila menggunakan model Altman (Z-Score), untuk mampu meningkatkan Z-Score ataupun meningkatkan kondisi keuangan, sebaiknya lebih mengoptimalkan pada penggunaan seluruh aktiva yang ada untuk meningkatkan penjualan, sehingga laba perusahaan juga diharapkan akan meningkat. Hal ini perlu dilakukan karena model Altman (Z-Score) lebih menekankan kepada keefektifan penggunaan sumberdaya (aktiva) yang dimiliki oleh perusahaan untuk menghasilkan pendapatan.

Apabila perusahaan menggunakan model Zavgren (Logit) untuk menurunkan probabilitas atau peluang kebangkrutan $(\mathrm{Pi})$ ataupun meningkatkan kondisi keuangan, sebaiknya perusahaan menyesuaikan jumlah quick asset tersedia dengan kebutuhan perusahaan dalam membiayai operasional dan pembayaran hutang jangka pendeknya, sehingga aktiva yang dimiliki perusahaan benar-benar digunakan secara optimal untuk menghasilkan laba. Hal ini perlu dilakukan karena model Zavgren (Logit) lebih menekankan pada kemampuan perusahaan dalam melunasi kewajiban yang segera jatuh tempo tanpa mengganggu aktivitas operasi perusahaan yang terkait dengan jumlah quick asset yang ada. Sebaiknya juga dilakukan analisis kondisi keuangan terhadap laporan keuangan secara terus menerus, sehingga perusahaan dapat mengetahui prestasi perkembangan di masa yang akan datang.

Ketiga, disarankan bagi para investor sebaiknya berhati-hati dalam pengambilan keputusan berinvestasi. Investor seharusnya memperhatikan rasio-rasio keuangan dari perusahaan. Sebaiknya sebelum pengambilan keputusan, dapat dilakukan analisis kondisi keuangan sehingga dapat diukur seberapa tinggi prospek perusahaan ke depan.

\section{DAFTAR PUSTAKA}

Agustina, Y. dan Rahmawati. 2010. Kebangkrutan Perusahaan menggunakan Model Altman dan Zavgren pada Perusahaan Food and Beverages. The Winners. Vol. 11, No. 1, hal.12-25.

Aprilaningsih, W. 2015. Analisis Prediksi Kebangkrutan Perusahaan dengan menggunakan Metode Altman ZScore pada Perusahaan Telekomunikasi Indonesia. Skripsi (tidak dipublikasikan). Surakarta: Jurusan Manajemen Fakultas Ekonomi dan Bisnis Universitas Muhammadiyah Surakarta. 
Baridwan, Z. 1992. Intemediate Accounting. Edisi Tujuh. Yogyakarta: BPFE.

Darsono dan Ashari. 2005. Pedoman Praktis Memahami Laporan Keuangan. Yogyakarta: Andi Offset.

Dewi, F.N. 2015. Prediksi Kebangkrutan dengan menggunakan Model Zavgren (Logit) (Studi Kasus pada Perusahaan Tekstil dan Garmen yang terdaftar di Bursa Efek Indonesia). Jurnal Ilmiah Mahasiswa FEB Universitas Brawijaya. Vol 4, No. 2, Semester Genap 2015/2016.

Fahmi, I. 2012. Analsis Laporan Keuangan. Bandung: Alfabeta.

Harahap, S.S. 2008. Teori Akuntansi. Jakarta: Rajawali Pers.

Harahap, S.S. 2011. Analisis Kritis atas Laporan Keuangan. Jakarta: PT. RajaGrafindo Persada.

Irfan, M. 2014. Analisis Financial Distress dengan Pendekatan Altman Z-Score untuk Memprediksi Kebangkrutan Perusahaan Telekomunikasi. Jurnal Ilmu \& Riset Manajemen. Vol. 3, No. 1, hal.1-18.

Jumingan. 2006. Analisis Laporan Keuangan. Jakarta: PT Bumi Aksara.

Kasmir. 2011. Analisa Laporan Keuangan. Jakarta: PT. RajaGrafindo Persada.

Munawir, S. 2007. Analisis Laporan Keuangan. Edisi Empat. Yogyakarta: Liberty.

Sugiyono. 2010. Metode Penelitian Kuantitatif, Kualitatif dan R\&D. Bandung: Alfabeta.

Wallace, W.A. 2004. Risk Assesment by Internal Auditors using Past Research on Bankruptcy. America: The Institute of Internal Auditors Research Foundation.

$\underline{\text { www.idx.co.id }}$ 